\title{
Pilotstudie: Naar een database van studenten en afgestudeerden van de Radiant Lerarenopleidingen Basisonderwijs (PABO)
}

Citation for published version (APA):

Cörvers, F., \& Vermeulen, S. (2019). Pilotstudie: Naar een database van studenten en afgestudeerden van de Radiant Lerarenopleidingen Basisonderwijs (PABO). ROA. ROA Reports No. 008 https://doi.org/10.26481/umarep.2019008

Document status and date:

Published: 06/12/2019

DOI:

10.26481/umarep.2019008

Document Version:

Publisher's PDF, also known as Version of record

Please check the document version of this publication:

- A submitted manuscript is the version of the article upon submission and before peer-review. There can be important differences between the submitted version and the official published version of record.

People interested in the research are advised to contact the author for the final version of the publication, or visit the DOI to the publisher's website.

- The final author version and the galley proof are versions of the publication after peer review.

- The final published version features the final layout of the paper including the volume, issue and page numbers.

Link to publication

\footnotetext{
General rights rights.

- You may freely distribute the URL identifying the publication in the public portal. please follow below link for the End User Agreement:

www.umlib.nl/taverne-license

Take down policy

If you believe that this document breaches copyright please contact us at:

repository@maastrichtuniversity.nl

providing details and we will investigate your claim.
}

Copyright and moral rights for the publications made accessible in the public portal are retained by the authors and/or other copyright owners and it is a condition of accessing publications that users recognise and abide by the legal requirements associated with these

- Users may download and print one copy of any publication from the public portal for the purpose of private study or research.

- You may not further distribute the material or use it for any profit-making activity or commercial gain

If the publication is distributed under the terms of Article $25 \mathrm{fa}$ of the Dutch Copyright Act, indicated by the "Taverne" license above, 
Maastricht University

Pilotstudie

Naar een database van studenten en

afgestudeerden van de Radiant

Lerarenopleidingen Basisonderwijs (PABO)

Frank Cörvers

Stan Vermeulen

\section{ROA Rapport}

ROA-R-2019/8

Researchcentrum voor Onderwijs en Arbeidsmarkt | ROA Research Centre for Education and the Labour Market / ROA 


\section{Colofon}

(C) Researchcentrum voor Onderwijs en Arbeidsmarkt (ROA). Niets uit deze uitgave mag op enige manier worden verveelvoudigd zonder voorafgaande schriftelijke toestemming van de directeur van het ROA.

\section{Researchcentrum voor Onderwijs en Arbeidsmarkt}

Postbus 616

6200 MD Maastricht

$\mathrm{T}+31433883647$

$\mathrm{F}+31433884914$

secretary-roa-sbe@maastrichtuniversity.nl

www.roa.nl

School of Business and Economics

Maastricht University

\section{Vormgeving}

ROA secretariaat, Maastricht

ISBN: 978-90-5321-586-9

november 2019

\section{NROO)}

Dit project is (mede) gefinancierd door het NRO. 


\section{INHOUD}

Voorwoord

$1 \quad$ Inleiding

2 Interviews met informatiespecialisten van lerarenopleidingen en betrokkenen

3 Inhoud lerarendatabase en instellingsrapportage

4 Gegevensuitwisseling hogescholen en CBS

5 Slot

Bijlage A

Bijlage B

Bijlage C

37 



\section{VOORWOORD}

Deze pilotstudie verkent de mogelijkheden, de wenselijkheden en de gevoeligheden bij het opzetten van een lerarendatabase. In de pilotstudie was de verkenning onder de Radiant Lerarenopleidingen Basisonderwijs (PABO) het startpunt, hoewel de resultaten van dit onderzoek ook grotendeels voor alle andere lerarenopleidingen van toepassing zijn. Wij danken de Colleges van Bestuur van Radiant Lerarenopleidingen voor de medewerking aan het onderzoek.

De begeleidingscommissie van deze pilotstudie is drie keer bijeen geweest in Utrecht (10 december 2018, 28 maart 2019 en 12 juni 2019). De begeleidingscommissie bestond uit drie leden: Robert Verbruggen, (Voorzitter College van Bestuur De Kempel), Anja Tertoolen, (Manager kenniscentrum iPabo, Coördinatie Radiantonderzoeksprogrammering) en Menno Pistorius (Directeur Faculteit Educatie HAN). De auteurs bedanken de leden van de begeleidingscommissie voor hun bijdrage in de totstandkoming van dit rapport. Verder zijn zij dank verschuldigd aan de geïnterviewden (zie Bijlage A) voor het verstrekken van de benodigde informatie en het NRO (in het bijzonder Jelle Kaldewaij en Niels Rijke) voor de financiering en begeleiding van het onderzoek.

1 Radiant Lerarenopleidingen bestaat uit een samenwerkingsverband van de volgende hogescholen: Christelijke Hogeschool Ede (CHE), Driestar hogeschool, Hogeschool De Kempel, Hogeschool iPabo, Iselinge Hogeschool, Katholieke Pabo Zwolle (KPZ), Marnix Academie, Thomas More Hogeschool en Hogeschool Viaa. 



\section{INLEIDING}

De lerarenopleidingen hebben de laatste jaren, mede in het kader van de Lerarenagenda 2013-2020 'De leraar maakt het verschil', veel gedaan om hun opleidingen te verbeteren. Maatregelen betreffen onder meer de invoering van de kennisbases en -toetsen, de toegenomen aandacht voor de kwaliteit van lerarenopleiders en het opzetten van opleidingsscholen. De hoofdvraag die bij al deze maatregelen gesteld kan worden is welke kenmerken van de curricula en van de studenten van de lerarenopleidingen er toe doen voor de onderwijsloopbaan van studenten en de beroepsloopbaan van beginnende leraren. De voorliggende pilotstudie beoogt de noodzakelijke voorbereidingen te treffen voor de verzameling van gegevens bij de lerarenopleidingen waarmee deze hoofdvraag zou kunnen worden beantwoord. Het onderzoek is geen pilotstudie in de zin van daadwerkelijke gegevensverzameling. Het is wel een pilotstudie in de zin van een verkenning van het draagvlak om onder de noodzakelijke voorwaarden (ten aanzien van bijvoorbeeld privacyrichtlijnen, toestemmingsvereisten en databeveiliging) in een volgende stap voor een beperkt aantal relatief eenvoudige variabelen een begin te kunnen maken met de gewenste dataverzameling.

Het onderzoek is een voortzetting en toespitsing van een eerdere verkenning door het $\mathrm{ROA}^{2}$, waarbij een grote inhoudelijke relevantie van met name de koppeling van studentgegevens van lerarenopleidingen aan registerbestanden van het CBS en DUO werd voorzien. Gegevens over de lerarenopleidingen en hoe de aankomende leraren deze hebben doorlopen zijn in grote mate te beschouwen als een ontbrekende schakel ('black box') in de veelheid van data die al beschikbaar zijn over de studenten vóórdat ze beginnen aan de lerarenopleiding (bijvoorbeeld gegevens over de sociaaleconomische situatie van het huishouden waarin ze zijn opgegroeid en over de eerdere schoolloopbaan in het funderend onderwijs) en nádat ze de lerarenopleiding hebben afgerond (de arbeidsmarktintrede en de vervolgloopbaan). De informatie over de voortgang en studieprestaties tijdens de lerarenopleidingen lijkt het belangrijkste ontbrekende onderdeel in de schoolloopbaan van afgestudeerde leraren, dat wellicht ook voorspellende waarde heeft voor de verdere beroepsloopbaan binnen of buiten het onderwijs. Het voorliggende onderzoek is vooral gericht op de PABO's die aangesloten zijn bij Radiant

2 B. Belfi, F. Cörvers, A. Mommers (2017), Naar een database van (startende) leraren en lerarenopleidingen: verkennend onderzoek naar de potentie en de wenselijkheid, ROA-R-2017/8, Maastricht University. 
Lerarenopleidingen, maar we kijken tevens of de resultaten generaliseerbaar zijn voor de andere lerarenopleidingen voor het basisonderwijs en het voortgezet onderwijs.

Het hoofddoel van deze pilotstudie is het inventariseren van de mogelijkheden om bestaande gegevens in de informatiesystemen bij de lerarenopleidingen van hogescholen beter te gebruiken en voor analyse geschikt te maken. In deze verkenning gaat het uitdrukkelijk niet om het genereren van nieuwe gegevens bij de lerarenopleidingen, wel om te kijken welke data in de bestaande administratieve systemen van de lerarenopleidingen interessant zijn voor het monitoren en verklaren van de studievoortgang van studenten en hun intrede op de arbeidsmarkt. Er zijn twee algemene doelen te formuleren bij de gegevensverzameling:

- Ten eerste zou elke lerarenopleiding die zelf gegevens aanlevert stuurinformatie terug moeten krijgen (een instellingsrapportage), waarmee de lerarenopleidingen zelf de inrichting van het curriculum kunnen evalueren en waar gewenst optimaliseren, door zich te vergelijken met (het gemiddelde van) de andere opleidingen. Mogelijk relevante stuurinformatie voor de lerarenopleidingen heeft betrekking op de studenteninstroom, de arbeidsmarktintrede en de onderwijsinzet en lespraktijken van afgestudeerde leraren. Voor het genereren van deze informatie moeten tevens gegevens over de afnemende scholen gebruikt worden.

- Ten tweede zou er een algemene database moeten komen waarmee relevante beleidsvragen beantwoord kunnen worden. Dit kan plaatsvinden op basis van de vergelijking van de curricula van de opleidingen, de intrede en voortgang van studenten van de lerarenopleidingen, de intrede op de arbeidsmarkt van beginnende leraren en hun functioneren als leraar. Het gaat hierbij om het blootleggen van algemene patronen, niet om het onthullen van instellingsspecifieke gegevens over de lerarenopleidingen.

\section{Aanpak}

Wat betreft de werkzaamheden in deze pilotstudie zijn er drie blokken te onderscheiden. Ten eerste het benaderen van de contactpersonen van de lerarenopleidingen die gaan over de informatie betreffende de studenten en hun studievoortgang, vaak onder de noemer studie- of studenteninformatiesysteem. In dit systeem zijn de studieresultaten van de verschillende onderdelen van het curriculum opgeslagen, en daarmee ook de inhoud en de opbouw van het curriculum. ${ }^{3}$ Deze gegevens in de informatiesystemen van de lerarenopleidingen zijn belangrijke input voor de lerarendatabase en de instellingenrapportages. We onderzoeken of de aangesloten opleidingen gebruik maken van dezelfde informatiesystemen en hoe deze zijn ingericht, in welke mate de curricula over-

3. Daarbij dient ook rekening te worden gehouden met het bestaan van verschillende trajecten en ook verschillende curricula binnen één lerarenopleiding, zoals voltijd/deeltijd en de academische PABO. 
eenkomen, en welke relevante variabelen beschikbaar zijn (bijv. curriculumonderdelen, studiepunten, BSA, etc.) uit de administraties van de hogescholen.

In het tweede blok kijken we naar de variabelen die reeds in de registerbestanden van het CBS beschikbaar zijn. Bovendien wordt er nagegaan welke van voor de hogescholen extern beschikbare variabelen interessant zijn voor de instellingsrapportage van een lerarenopleiding en voor de lerarendatabase. Er wordt in samenspraak met de begeleidingscommissie een selectie gemaakt van de relevante variabelen. De basisgedachte is dat hogescholen in ruil voor hun medewerking in de aanlevering een rapportage krijgen waarin ze de studentenpopulatie, de studievoortgang, het curriculum en de arbeidsmarktintrede van hun lerarenopleiding kunnen vergelijken met het gemiddelde van de andere lerarenopleidingen op basis van een beperkte maar inzichtelijke set van variabelen.

Ten derde kijken we naar hoe de aanlevering door de hogescholen er concreet moet uitzien, evenals de bestandsopbouw van de lerarendatabase. Dit wordt medebepaald door de aanlevering van de hogescholen, en door de privacy-gevoeligheid van gegevens en de toestemmingsvereisten van het CBS en de hogescholen. Wat dat laatste betreft wordt er nadrukkelijk aangesloten op al bestaande praktijken voor de aanlevering van gegevens door scholen aan derden, waaronder het Nationaal Cohortonderzoek Onderwijs (NCO). Daarbij geldt als bijzondere omstandigheid dat het hier instellingsgegevens betreft, waarvoor het CBS strikte voorwaarden stelt ten aanzien van identificatie, aanlevering aan derden en publicatie. Ook wordt er een samenvattend inzicht gegeven de mogelijkheden van het gebruik van registerbestanden van het CBS of andere bestanden en de kosten voor aanlevering van gegevens aan CBS.

Dit rapport is als volgt opgebouwd. In hoofdstuk 2 doen we verslag van de interviews met de contactpersonen bij voornamelijk de Radiant Lerarenopleidingen. Daarnaast is in dit hoofdstuk een samenvatting gemaakt van de interviews met vertegenwoordigers van andere instellingen, waaronder het CBS, het NCO en de LOBO. Hoofdstuk 3 geeft inzicht in de mogelijkheden die de gegevens van de lerarenopleidingen bieden in combinatie met de al ruimschoots beschikbare registerbestanden over leraren. Hoofdstuk 4 gaat verder in op de uitvoering van de data-aanlevering door hogescholen aan het CBS en de voorwaarden en voorzorgsmaatregelen omtrent privacy en beveiliging die daarbij van belang zijn. Hoofdstuk 5 sluit af met de belangrijkste bevindingen en enkele aanbevelingen. 



\section{INTERVIEWS MET INFORMATIESPECIALISTEN VAN LERARENOPLEIDINGEN EN BETROKKENEN}

In dit hoofdstuk geven we een samenvatting van de interviews die zijn afgenomen bij medewerkers van de studentenadministratie van hogescholen en vertegenwoordigers van enkele andere sleutelorganisaties. Het ging daarbij vooral om medewerkers van Radiant-hogescholen die een PABO aanbieden. De medewerkers van de studentenadministratie, die we interviewden deels op voordracht van de begeleidingscommissie, hadden min of meer dezelfde achtergrond. Toch bleken zij vaak verschillende takenpakketten en verantwoordelijkheden te hebben. De verscheidenheid in achtergrond tussen de geïnterviewden weerspiegelt volgens ons de verscheidenheid in de wijze waarop hogescholen de studentenadministratie hebben ingericht.

De hoofdvraag was in hoeverre de lerarenopleidingen in staat zijn om informatie over het curriculum en de studievoortgang uit de studentenadministratie aan te leveren ten behoeve van een lerarendatabase. Daarnaast hebben we gesproken met andere personen die ons gegevens konden verstrekken over de wenselijkheid en de mogelijkheden voor een dergelijke aanlevering vanuit de lerarenopleidingen. In Bijlage A staat het overzicht van alle geïnterviewde personen met de instelling die ze vertegenwoordigen (inclusief verklaring van de afkortingen).

\section{Interviews met informatiespecialisten van lerarenopleidingen}

In de interviews met informatiespecialisten zijn we begonnen met te vragen naar hoe en welke gegevens er in het studieinformatiesysteem (of studenteninformatiesysteem, SIS) van de lerarenopleidingen zijn opgeslagen over studenten en het curriculum.

De volgende vragen zijn onder meer gesteld:

1. Welke softwarepakketten gebruikt uw school voor de registratie van de instroom, de studievoortgang, het curriculum en de uitstroom? Bijv. Osiris, Alluris, Trajectplanner?

2. Is er documentatie incl. meta-informatie beschikbaar over de gegevensopslag?

3. Is vastgelegd welke vakken een student heeft doorlopen, wanneer examen is gedaan, wanneer de student stage heeft gelopen, en het behaalde resultaat?

4. Hoe zijn de verschillende variabelen vergelijkbaar of vergelijkbaar te maken met andere lerarenopleidingen? 
5. Een deel van deze gegevens (bijv. over rendementen) wordt aangeleverd aan DUO. Is een dergelijke aanlevering aan DUO of CBS eenvoudig uit te breiden voor andere variabelen?

In antwoord op deze vragen kan de volgende samenvatting worden gemaakt.

\section{Softwarepakketten}

Op het moment van het schrijven van dit rapport gebruiken vijf van de negen PABO's die zijn aangesloten bij Radiant Trajectplanner (https://www.trajectplanner.nl/). De iPABO en een brede hogeschool als de Christelijke Hogeschool Ede (CHE) maken gebruik van Osiris (https://www.caci.nl/nl/), KPZ en Thomas Moore van Alluris (https://www. iddinkgroup.com/ons-bedrijf/alluris/). Osiris blijkt met name voor de grote, brede hogescholen interessant te zijn; zo wordt het pakket ook naar tevredenheid gebruikt bij Zuyd Hogeschool dat niet bij Radiant is aangesloten. Trajectplanner wordt vooral door de kleine hogescholen gebruikt. Alluris is een pakket dat afkomstig is uit het mbo-veld, en zit er qua gebruikersgroep tussenin. Het gebruik van Alluris wordt echter uitgefaseerd, zoals aangegeven door de leverancier. Dit lijkt ook te gelden voor Trajectplanner. Andere pakketten die bij brede hogescholen worden gebruikt zijn Progress (zie https://www. progressonderwijs.nl/referenties) en SaNS (https://sans-ec.nl/).

Alle pakketten kunnen via internet worden benaderd. De gegevens zijn centraal op de servers van de pakketleveranciers opgeslagen. Er kan bovendien een lokale kopie van de databestanden worden gemaakt. De benadering van de databestanden gebeurt vanuit verschillende voorgedefinieerde 'rollen': studentenadministratie (inschrijven, uitschrijven, registratie behaalde propedeuse, voortgang en diplomering), cijferadministratie, decaan, docent, roosteradministratie. Per rol is er een andere toegang tot de gegevens. Daarnaast zijn er door vrijwel alle hogescholen verschillende systemen door de ICT-afdeling zelf gebouwd, bijvoorbeeld voor de registratie van stages en voor de managementrapportages. Er lijkt daarbij een grote verscheidenheid te zijn van zelf 'gebouwde' dan wel geprogrammeerde systemen voor verschillende onderdelen van de studentenadministratie (zoals studievolgdeel, stagedeel, inschrijfdeel, etc.).

\section{Beschikbaarheid meta-informatie}

De meta-informatie is niet beschikbaar bij één persoon of in één bestand. Er zijn verschillende afdelingen en verschillende softwareprogramma's van waaruit de aanleveringen moeten gebeuren. Er is geen documentatie van de database of de programmatuur beschikbaar. Over het algemeen is er geen beschrijving bekend van de bestanden of de werkprocessen. Soms zijn er wel overdrachtsdocumenten voor de eigen werkzaamheden. Het softwarepakket is vaak voldoende voor de export van kolommen uit de studentenadministratie naar Excel om vervolgens daarin verder te werken. 


\section{Administratie en rapportage van studentgegevens en studievoortgang}

In principe heeft men de beschikking over alle gegevens per student. Belangrijk zijn vooral de voorgedefinieerde standaardtabellen. Die standaarden maken het moeilijk om additionele variabelen te onttrekken aan de database, bijvoorbeeld over de vooropleiding. Sommige hogescholen hebben niet de beschikking over een programmeur en ICT-afdeling die met aparte programma's variabelen uit de database kan onttrekken. Alleen de standaardkolommen kunnen dan worden geëxporteerd naar Excel. De communicatie met de softwareleverancier loopt bovendien niet altijd soepel waardoor het moeilijk is om aanpassingen in de standaardoutput door te voeren.

De vorm waarin kan worden gerapporteerd staat vaak vast. Variabelen over studenten staan bovendien in verschillende standaardtabellen die moeten worden gekoppeld via Excel als men informatie wil combineren voor verdere analyses. Dat is foutengevoelig en arbeidsintensief. Een uitgebreide standaardtabel zou bijvoorbeeld 40 variabelen kunnen bevatten die een zogeheten primaire status hebben, met bijv. behaalde vakken, studiepunten, datum van examen, bsa, studiekeuzecheck en collegegeldbetaling. Een heel aantal variabelen staan wel in de database maar kunnen vaak alleen per student worden ingezien, bijvoorbeeld de variabele herkansingen en de variabele vooropleiding.

Het is vaak onduidelijk of en welke informatie precies in de centrale database op de server van de pakketleverancier is vastgelegd. Men kan deze database vaak niet benaderen of eenvoudig inzien. Zo zijn er bijvoorbeeld soms moeilijkheden met het overschrijven van eerdere informatie, zoals het vastleggen van de laatste behaalde vooropleiding, die alle vorige vooropleidingen lijkt te overschrijven. Of dat daadwerkelijk gebeurt is onduidelijk, want daarvoor zou men de centrale database moeten kunnen benaderen.

\section{Vergelijkbaarheid van gegevens tussen lerarenopleidingen}

Per instelling lijken er verschillende databases te zijn, en verschillende standaardtabellen. Er is centrale opslag via (de servers van) de softwareleveranciers. Er is overleg met collega's van andere instellingen en er is een gebruikersgroep om samen met Trajectplanner te kijken naar de mogelijkheden voor aanpassingen. Vanzelfsprekend zijn de behaalde vakken tussen instellingen niet goed vergelijkbaar omdat de roosters en curricula nogal verschillen. Ook kan er bij de ene instelling sprake zijn van grote eenheden die gehaald moeten worden en bij andere van vele kleine vakken. Bij de softwareleveranciers is mogelijk wel inzicht in hoe vanuit verschillende onderwijsinstellingen de gegevens zijn opgeslagen omdat daar de centrale opslag is geregeld. Om de curricula en voortgang van studenten van lerarenopleidingen onderling te vergelijken lijken de behaalde studiepunten van studenten (ECTS) en de verplichte onderdelen (zoals kennisbasistoetsen) de meest kansrijke variabelen te zijn. 


\section{Aanlevering aan DUO of CBS}

Mutaties over studenten worden aan DUO via Trajectplanner en het daaraan gekoppelde Studielink doorgegeven. Dit gebeurt dagelijks gedurende het gehele jaar voor zowel inschrijvingen, uitschrijvingen als diplomering. Rendementsgegevens over de opleiding worden vanuit een andere afdelingen aan DUO doorgegeven. Ook worden tellingen door DUO teruggeleverd aan de instellingen ter controle en eventuele aanpassing.

Uit de interviews is gebleken dat het teveel gevraagd is aan de lerarenopleidingen en waarschijnlijk zelfs hogescholen in het algemeen om een aparte data-aanlevering te doen van relevante variabelen uit de studentenadministratie. Dit zou een vergaande voorbereiding vergen omdat de systemen daar helemaal niet op ingericht zijn en aanpassingen hierin over het algemeen erg bewerkelijk zijn. Dit blijkt ook als informatiespecialisten andere tabellen dan de standaardtabellen moeten aanleveren voor intern gebruik, bijvoorbeeld managementinformatie voor het College van Bestuur: bij veel lerarenopleidingen is dit geen sinecure. ${ }^{4} \mathrm{Er}$ is over het algemeen dan ook een wens om flexibeler en sneller over studenten met verschillende studentkenmerken en hun voortgang te kunnen rapporteren.

Gaandeweg de gesprekken is gebleken dat de aanlevering van gegevens over de studievoortgang van studenten en inrichting van de curricula alleen van de softwareleveranciers van de diverse pakketten kan worden verwacht. Het voordeel van de softwareleveranciers is dat ze vanuit hun servers voor een aantal gestandaardiseerde variabelen één levering met dezelfde bestandopbouw voor verschillende hogescholen tegelijk aan CBS zouden kunnen doen.

\section{Interviews met andere betrokkenen}

Er is gesproken met diverse andere betrokkenen, in het bijzonder over de wenselijkheid en mogelijkheid van een lerarendatabase en van instellingsrapportages. Uit het gesprek met de voorzitter van de LOBO (eerder voorzitter CvB Marnixacademie, zie Bijlage A) en de daarop volgende bijeenkomst van de $L O B O$ leken de lerarenopleidingen van de PABO, met de nodige reserves (zie hieronder), wel interesse te hebben in het onderzoek over de lerarendatabase. Dit biedt mogelijk een perspectief op een groter draagvlak onder de PABO-opleidingen, daar waar eerder voornamelijk de zelfstandige PABO's verenigd in Radiant interesse hadden. Uit de dialoog met de LOBO is het volgende gebleken:

- Instellingsrapportages over studentkenmerken en curricula waarbij de eigen instelling wordt vergeleken met het gemiddelde van andere zijn interessant en lijken een nuttige aanvulling op de bestaande managementinformatie te zijn.

4 Zo zijn sommige lerarenopleidingen niet in staat om de gemiddelde studievoortgang (in studiepunten) te rapporteren voor de deelpopulaties van studenten met een havo- dan wel mbo-achtergrond. 
- De curricula zouden wel vergeleken kunnen worden op een aantal standaardvariabelen, zoals studiepunten, uitval, diplomering en kennisbasistoetsen.

- Desondanks zijn er ernstige bedenkingen bij de vergelijkbaarheid van de curricula, welke ook nog vaak jaarlijks aan veranderingen onderhevig zijn. Dat geldt voor onder meer het vergelijken van studiepunten op peildata, en des te meer voor de stageperiodes: stages en organisatie van stages en waardering van stages zijn heel verschillend.

- Ook zijn er twijfels over de verschillende aannames voor onderzoek, bijvoorbeeld bij de koppeling studentkenmerken en studiesucces (hoe hard is die koppeling te maken, hoe 'gevaarlijk' is die ook?); de koppeling studiesucces - curriculum (dat gaat voorbij aan informeel leren); de koppeling curriculum - goed landen in de arbeidsmarkt.

- Het gebruik van studentkernmerken als etniciteit en geslacht wordt als potentieel zeer gevoelig gezien.

- Het vergelijken van kwantitatieve gegevens geeft slechts een indruk van de mogelijke verschillen zonder dat de verklaringen evident zijn. De interpretatie van de verschillen staat dan nog open. Er is aanvullende duiding en kwalitatief onderzoek benodigd om conclusies te kunnen te trekken.

- Men maakt zich zorgen dat de gegevens over instellingen bij het ministerie van OCW en bij de Inspectie van het Onderwijs terecht kunnen komen omdat men vreest voor maatregelen op basis van 'benchmarking', zonder dat de verklaringen voor verschillen tussen lerarenopleidingen evident zijn.

- Er zijn zorgen over de privacy-gevoeligheid van de gegevens en of, en in welke vorm, scholen gegevens over studenten mogen doorleveren aan derden, mede in het licht van de AVG.

Uit de dialoog met andere betrokkenen (begeleidingscommissie, NCO, CBS, hogeschoollector aan lerarenopleiding, Inspectie van het Onderwijs, leveranciers softwarepakketten) is gebleken:

- De opzet van een lerarendatabase met daaruit voortkomende instellingsrapportages is zeer interessant voor publicatie en onderzoek en als managementinformatie, waarbij wel de vertrouwelijkheid van gegevens op instellingsniveau in acht moet worden genomen.

- Lerarenopleidingen mogen dan wel qua curricula verschillend zijn, toch blijven er voldoende variabelen over waarop ze wel vergeleken kunnen worden.

- Zowel de koppeling met externe bestanden (bij het CBS) als de benchmarking worden interessant bevonden. Het gaat daarbij niet alleen om opleidingsrendement (studievoortgang/uitval, stageperiode) maar ook beroepsrendement (uitval uit beroep/sector, locatie werkplek, inductiebeleid afnemende scholen, etc.). Duidelijk is dat een verdiepingsslag naar aanleiding van een instellingsrapportage nodig is om conclusies te kunnen trekken. Dat zal kunnen door verdere kwantitatieve analyses, en/of door kwalitatief onderzoek zoals onderlinge uitwisseling van de uitkomsten. 
- Aanlevering aan het CBS vanuit de servers van de leveranciers van de softwarepakketten voor de studentenadministratie is de meest duidelijke route voor het samenstellen van de instellingsrapportages en de lerarendatabase. Hiermee is ook al ervaring opgedaan binnen het Nationaal Cohortonderzoek Onderwijs (NCO) voor de pilot Leerlingvolgsystemen (LVS) met inachtneming van de AVG. ${ }^{5}$

- Het lijkt raadzaam te zijn de aanlevering van gegevens in eerste instantie vooral te beperken tot enkele standaardgegevens die met zekerheid vergelijkbaar zijn tussen de instellingen en waarvoor geen of nauwelijks verdere bewerkingen noodzakelijk zijn. De belangrijkste en meeste interessante variabele lijkt hier studievoortgang te zijn, uitgedrukt in bijvoorbeeld behaalde studiepunten van een cohort per maand, kwartaal of jaar. Ook datum van inschrijving en uitschrijving, datum propedeuse- en bachelordiploma, en datum kennisbasistoetsen zijn daarbij vanzelfsprekend interessant.

$\overline{5}$ Zie bijvoorbeeld https://nationaalcohortonderzoek.nl/nieuws/pilot-po-met-lvs-data/ 


\section{INHOUD LERARENDATABASE EN INSTELLINGSRAPPORTAGE}

In dit hoofdstuk willen we een indruk geven van zowel de rijkdom aan gegevens die een lerarendatabase in potentie kan omvatten als de mogelijke relevantie van deze gegevens ten behoeve van managementinformatie voor het beleid van hogescholen. We zullen bovendien de aanlevering van student- en curriculumgegevens vanuit de hogescholen toespitsen op de variabelen die om een voorzichtig begin te maken als eerste aangeleverd zouden moeten worden.

\section{Gegevens lerarendatabase}

Bijlage B bevat een overzicht van alle bestanden die al bij het CBS beschikbaar zijn over leraren. De in de bijlage genoemde bestanden over leraren worden al bij diverse onderzoeksgroepen in Nederland gebruikt. Het betreft de volgende bestanden:

- Bestanden met leraarkenmerken, dat wil zeggen wie zijn er afgestudeerd aan de lerarenopleidingen, wat was hun cito-score en schooladvies op de basisschool, wat waren de examenresultaten op het voortgezet onderwijs, welke vervolgopleidingen zijn er gedaan, en wat was de gezinssituatie (SES), herkomst, de opleiding en het inkomen van de ouders van de leraren. Deze gegevens zijn beschikbaar in het NCO-bestand.

- Bestanden met de arbeidsmarktpositie van leraren, dat wil zeggen in welke sector, bij welk bestuur, in welke school, met welk contract en tegen welke lonen zijn afgestudeerden van de lerarenopleidingen werkzaam.

- Bestanden met gegevens over de leerlingenpopulatie van de scholen waaraan leraren in het primair en voortgezet onderwijs werkzaam zijn, dat wil zeggen gegevens op bestuurs- of schoollocatieniveau over bijvoorbeeld het aantal leerlingen, het aandeel meisjes, het percentage allochtonen, het gemiddelde citoniveau en de examenscores van de scholen in het voortgezet onderwijs. Ook deze gegevens zijn al beschikbaar in het NCO-bestand.

Uit het bovenstaande blijkt dat er al zeer veel bekend is over afgestudeerde leraren. De informatie over de voortgang en studieprestaties tijdens de lerarenopleidingen is het belangrijkste ontbrekende onderdeel in de schoolloopbaan van afgestudeerde leraren. 
Dit is informatie die bovendien zeer belangrijk kan zijn voor de verdere beroepsloopbaan. Het betreft gegevens van de lerarenopleidingen over:

- Instroom-, doorstroom en uitstroomgegevens van studenten; ${ }^{6}$

- De voortgang van studenten, incl. doorlopen vakken en behaalde cijfers, kennisbasistoetsen en stages;

- De gegevens over de curriculuminhoud, bijvoorbeeld studiepunten (ECTS), naam en inhoud vak, duur en periode, welke competenties worden afgedekt per vak en onderdeel.

De vraag is hoe de informatie over de zeer verschillende curricula van lerarenopleidingen eenduidig in een database kunnen worden weergeven. De meeste mogelijkheden om dit te doen bieden gemeenschappelijke onderdelen zoals stageperiodes (wellicht vooral de timing omdat ze qua aard en organisatie flink van elkaar kunnen verschillen), en verder studiepunten, kennisbasistoetsen, waarbij misschien een verdeling te maken is naar vakinhoudelijke, vakdidactische en pedagogische vakken. Gegevens over studenten zijn relatief gemakkelijk eenduidig weer te geven, naar bijvoorbeeld geslacht, herkomst of vooropleiding. Bij het presenteren van alle gegevens blijft het wel de vraag in hoeverre bijvoorbeeld de voortgang van studenten afhankelijk is van de lerarenopleiders (de docenten), en in welke mate van de curriculumopzet of van de studentkenmerken. Interessant kan verder zijn het opleidingsrendement te corrigeren voor bijvoorbeeld studentkenmerken, om te filteren op bepaalde kenmerken of om patronen bloot te leggen.

\section{Instellingrapportage voor hogescholen}

- De mogelijkheden voor een instellingsrapportage voor hogescholen zijn gebaseerd op: - Reeds beschikbare cijfers uit diverse bronnen die bij CBS zijn gekoppeld; deze bronnen worden al gebruikt bij onder andere het CPB, de Inspectie van het Onderwijs en universiteiten en onderzoeksinstellingen.

- De nieuw daaraan te koppelen gegevens die uit de administratieve systemen van de lerarenopleidingen worden aangeleverd.

Instellingsrapportages kunnen vanzelfsprekend op veel verschillende manieren vorm krijgen. Over de exacte invulling van een instellingsrapportage dient met de hogescholen te worden overlegd. Wel hebben we afgetast wat men mogelijk interessant zou vinden gedurende de presentaties en gesprekken voor de begeleidingscommissie, bij de LOBO en met andere betrokken (zie hoofdstuk 2). Voorbeelden van al bestaande instellingsrapportages voor het primair en voortgezet onderwijs zijn te vinden op de website van het NCO (https://nationaalcohortonderzoek.nl/rapportage-aanvragen/).?

6 Strikt genomen zijn deze in- en uitstroomgegevens van studenten al bekend via DUO.

7 Zie voor een voorbeeldrapportage van een school in het primair onderwijs: https://nationaalcohortonderzoek.nl/uploads/2019/03/20180918-Voorbeeldrapportage_ponieuwste-versie. pdf 
De volgende opsomming bevat de mogelijke output in een rapportage voor de lerarenopleidingen van hogescholen. Op basis van data die op dit moment beschikbaar is (zie Bijlage B en hierboven) kan het volgende worden weergegeven in een instellingsrapportage:

1. Kenmerken instromers per jaar en trends, eigen instelling ten opzichte van het landelijke (pabo)-gemiddelde

- Aantal instromers

- Geslacht, etniciteit, leeftijd, vooropleiding, type student (voltijd/deeltijd), aantal eerder gevolgde studies (evt. zij-instroom)

- Sociaaleconomische situatie (SES) van instromers op basis van hoogste opleiding ouders en huishoudinkomen

- Middelbare school profiel, CE en SE-cijfers per vak

- Eindtoetsscore basisschool

2. Kenmerken switchers, uitvallers, geslaagden, eigen instelling ten opzichte van het landelijke (pabo)-gemiddelde

- Percentage uitval \& switch na 1 en 4 jaar, diplomarendement

- Vergelijking van de kenmerken uitvallers/geslaagden op basis van dezelfde kenmerken als bij de instromers

3. Uitkomsten op de arbeidsmarkt geslaagden, eigen instelling ten opzichte van het landelijke pabo-gemiddelde o Percentage werkzaam in het onderwijs/voor de klas 1 en 5 jaar na afstuderen

- Percentage werkzaam buiten het onderwijs of werkloos 1 en 5 jaar na afstuderen

- Gemiddeld uurloon, baanomvang, contractstatus, inschaling functiemix

- School-, leerling- en collega-kenmerken van school waarop wordt lesgegeven

Wanneer er ook data uit de administratieve systemen van de lerarenopleidingen worden aangeleverd is in beginsel ook het volgende mogelijk:

4. Prestaties van studenten tijdens de lerarenopleiding

- Prestaties op vakinhoudelijke, vakdidactische, pedagogische vakken en stages en hun samenhang met studentkenmerken en uitkomsten op de entree- en reken/taaltoets

- Voorspellende waarde studiekeuzecheck op prestaties binnen lerarenopleiding

- Voorspellende waarde van prestaties in de lerarenopleiding voor arbeidsmarktuitkomsten

- Vergelijking tussen het curriculumaanbod aan vakken van de eigen instelling en het landelijk gemiddelde 
Op basis van studentgegevens die beschikbaar zijn in de administratiebestanden van DUO, en de arbeidsmarktbestanden die beschikbaar zijn binnen de CBS Microdata remote access omgeving, kunnen per instelling rapportages worden opgesteld. In deze rapportages kunnen de kenmerken en prestaties van de studenten van de eigen instelling worden vergeleken met het landelijke gemiddelde van alle andere instellingen. Hiermee wordt voor de instelling inzichtelijk op welke uitkomsten ze goed presteren, en waar mogelijke aandachtspunten zich bevinden. In deze paragraaf geven we aan de hand van enkele grafieken op basis van fictieve gegevens voorbeelden van wat voor type informatie in de instellingsrapportages kan worden opgenomen.

FIGUUR 3.1 Gemiddelde citoscore instromers 2017/2018 (fictief)

$550 \_$MB04 instromers $\square$ HAV0 instromers $\square$ VW0 instromers

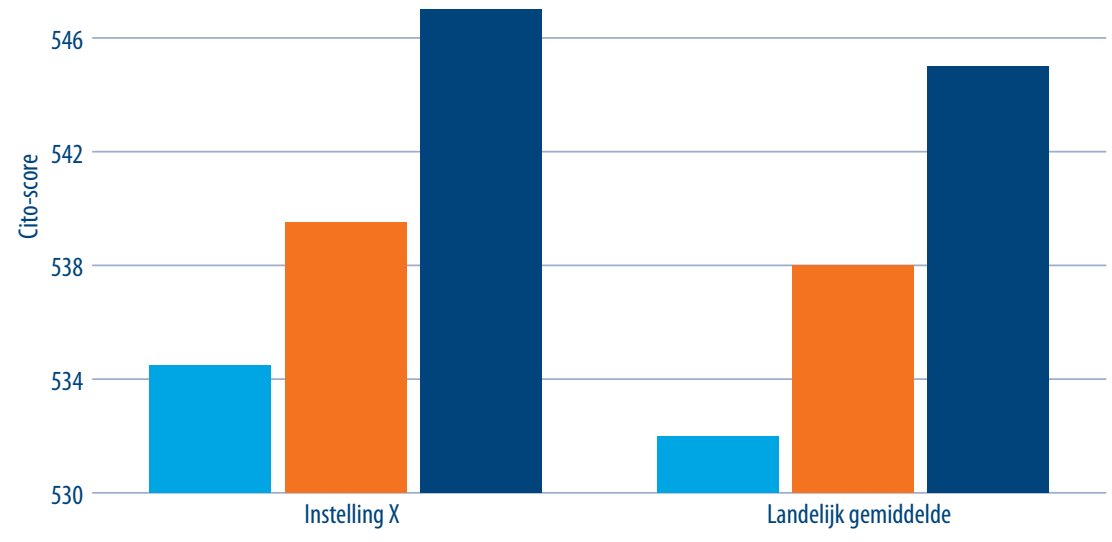

Figuur 3.1 toont voor de studenten die in het academisch jaar 2017/2018 zijn ingestroomd de gemiddelde citoscore naar vooropleiding van de eigen instelling ten opzichte van het landelijke gemiddelde. Dit is een voorbeeld van gegevens waarmee de kenmerken van de instroom inzichtelijk worden gemaakt. Naast gegevens over (prestaties tijdens) de vooropleiding (in het po of vo) kan de instroom ook uitgesplitst worden naar demografische kenmerken zoals herkomst en geslacht, en sociaaleconomische achtergrond zoals opleidingsniveau ouders en huishoudinkomen. Op basis van deze informatie kunnen lerarenopleidingen hun curriculum optimaliseren voor het specifieke type student dat zich voor hun instelling inschrijft. 
FIGUUR 3.2 Percentage studenten dat nog in de opleiding verblijft naar geslacht (fictief)

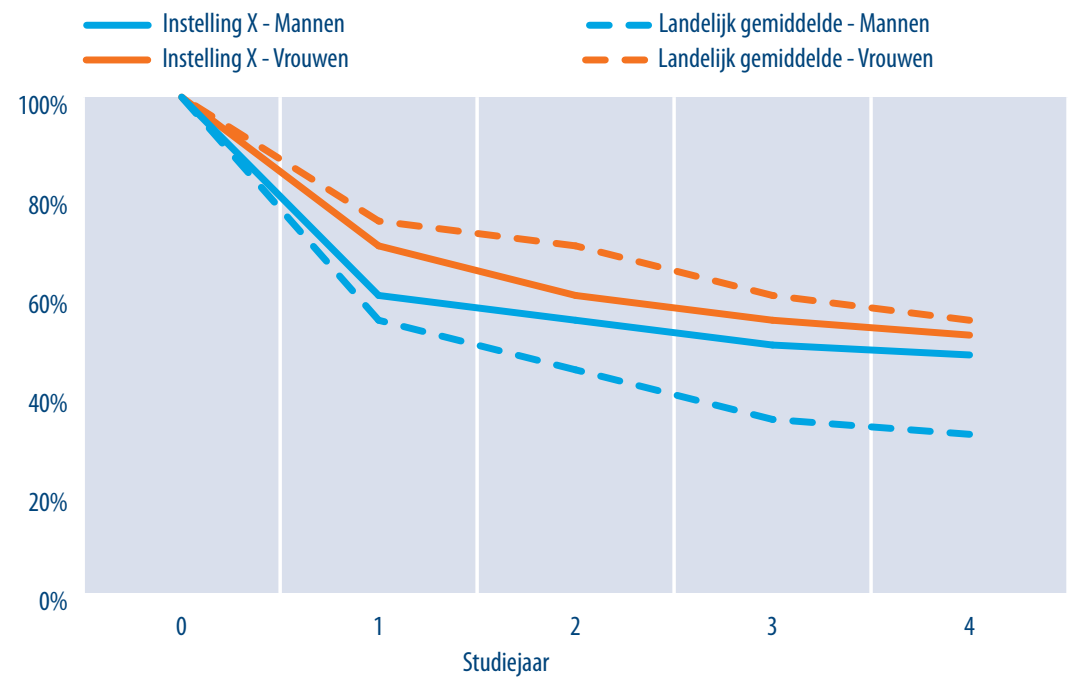

In Figuur 3.2 wordt per studiejaar aangegeven welk percentage van de studenten die in jaar o zijn begonnen nog in de opleiding verblijft. In dit geval is er uitgesplitst naar geslacht. Deze informatie is een voorbeeld van kenmerken van de studievoortgang, switchers, uitvallers, en afgestudeerden. Hiermee wordt voor de betreffende instelling inzichtelijk dat zij goed presteert op het binnen boord houden van haar mannelijke studenten, maar dat ze voor het behoud van de vrouwelijke studenten minder hoog scoort dan het landelijk gemiddelde. Deze informatie biedt aanknopingspunten voor lerarenopleidingen om hun rendement te verhogen door beleid te richten op groepen die binnen hun instelling het grootste risico hebben om de eindstreep niet te halen. Hiernaast kan eventueel ook inzichtelijk worden gemaakt waar studenten die uitvallen naartoe switchen: kiezen ze voor een andere studie, voor een andere lerarenopleiding, of vallen ze juist helemaal uit het hoger onderwijssysteem? 
FIGUUR 3.3 Percentage studenten dat na afstuderen werkzaam is in de onderwijssector (fictief)

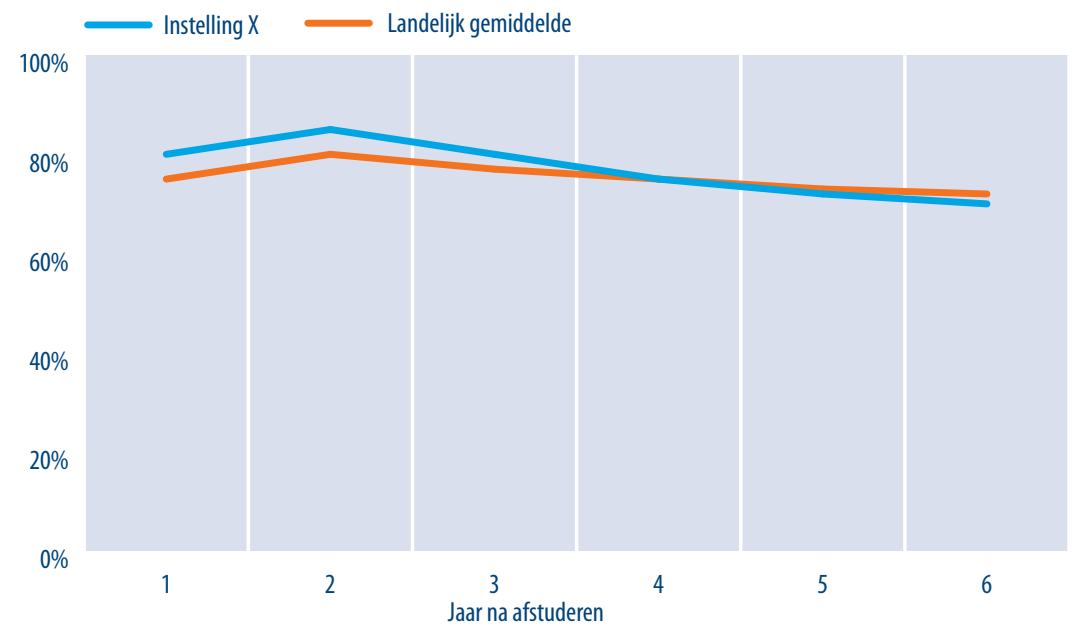

Figuur 3.3 laat het percentage geslaagden zien dat na het behalen van de lerarenopleiding binnen het onderwijs aan het werk is enkele jaren na afstuderen. Dit is een voorbeeld van de uitkomsten op de arbeidsmarkt van afgestudeerde studenten die in de instellingsrapportages kan worden opgenomen. In dit geval vinden de geslaagden van de eigen instelling vaker een baan in het onderwijs meteen na afstuderen, maar vallen ze na enkele jaren op de arbeidsmarkt ook relatief vaak uit. Voor de betreffende lerarenopleiding is dit wellicht een signaal om oud-studenten ook relatief lang na afstuderen nog te volgen en eventueel te ondersteunen. Andere voorbeelden van arbeidsmarktuitkomsten die in kaart kunnen worden gebracht zijn het gemiddelde uurloon, aanstellingsgrootte in $\mathrm{FTE}$, en percentage afgestudeerden met een vast contract. Ook deze gegevens kunnen worden uitgesplitst naar verschillende demografische en sociaaleconomische kenmerken. 
FIGUUR 3.4 Studievoortgang in ECTS per semester naar behaalde citoscore student (fictief)

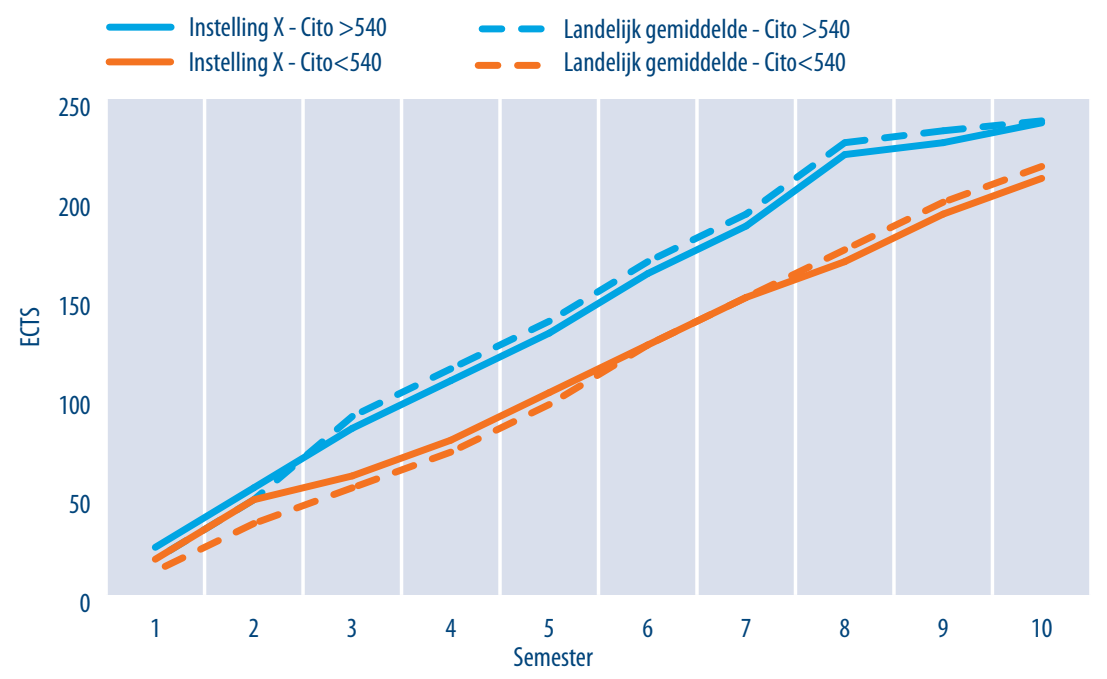

Wanneer naast de huidige beschikbare administratieve gegevens vanuit DUO en het CBS ook informatie wordt aangeleverd vanuit de lerarenopleidingen zelf, kunnen grafieken zoals Figuur 3.4 ook worden toegevoegd in de instellingsrapportages. Figuur 3.4 laat de studievoortgang van studenten per semester in ECTS zien ten opzichte van het landelijke gemiddelde, apart voor studenten met een relatief hoge en een relatief lage score op de CITO-eindtoets. Naast informatie over de studievoortgang kunnen met de instellingsgegevens ook analyses worden getoond over de voorspellende waarde van prestaties tijdens de lerarenopleiding voor uitkomsten op de arbeidsmarkt. Ook hier kunnen weer verschillen tussen de eigen instelling en het landelijke gemiddelde van de lerarenopleiding worden getoond, en worden uitgesplitst naar verschillende demografische en sociaaleconomische kenmerken.

Bovenstaande zijn slechts enkele voorbeelden van informatie die in de instellingsrapportages kan worden opgenomen. In overleg met de deelnemende lerarenopleidingen zal worden besloten welke gegevens voor de lerarenopleidingen het meest relevant zijn om te tonen in de rapportages.

\section{Toespitsing aanlevering door lerarenopleidingen}

In de praktijk zal het niet eenvoudig zijn om te komen tot een set aan variabelen die voor elke lerarenopleiding min of meer vergelijkbaar is. Dit is zelfs het geval als het uitsluitend PABO's betreft die nog het best onderling vergelijkbaar zijn, zoals een aantal PABO's van Radiant met dezelfde softwarepakketten. De belangrijkste reden hiervoor is dat de curricula tussen dezelfde lerarenopleidingen van de diverse hogescholen nogal van elkaar en tussen studiejaar kunnen verschillen. Op tenminste één variabele zal dat 
niet het geval zijn, namelijk het aantal behaalde studiepunten, ondanks dat de curricula nogal verschillend kunnen zijn qua opbouw (bijvoorbeeld enkele grote blokken versus veel kleine).

De variabelen op studentniveau die wat ons betreft bij het opstarten van de aanlevering na goedkeuring door de lerarenopleidingen als eerste in aanmerking komen zijn:

- Student ID (BSN maar bij voorkeur onderwijsnummer als pseudoniem)

- Naam/code/resultaat/datum afgelegde toetsen

- Naam/code/resultaat/datum verplichte onderdelen zoals toetsen voor de kennisbasis

- Behaalde studiepunten (ECTS) op aantal peildata

- Datum uitval of uitstroom

- Datum behaalde diploma's (propedeuse, bachelor)

In Bijlage $\mathrm{C}$ is een voorbeeld opgenomen van een bestand dat geschikt zou kunnen zijn voor aanlevering vanuit de administratiesystemen van de lerarenopleidingen aan het CBS. Een dergelijk bestand dient gedocumenteerd te worden op basis van een zogeheten codeboek. Op basis van de bevindingen uit het voorgaande hoofdstuk gaan we er vanuit dat de gegevens zijn opgeslagen op de servers van de softwareleveranciers. De softwareleveranciers kunnen de aanlevering uitvoeren na akkoord van de hogescholen en op basis van de voorwaarden die daarvoor wettelijk vereist zijn en door het CBS verlangd worden ten aanzien van de privacy van de studenten en de identificeerbaarheid van de opleidingen. 


\section{GEGEVENSUITWISSELING HOGESCHOLEN EN CBS}

Op basis van de bevindingen in dit onderzoek kunnen we een voorstel formuleren voor de samenstelling van een lerarendatabase en de samenstelling van instellingsrapportages. Het voorstel zoals het in dit hoofdstuk wordt gedaan, is een concept dat als uitgangspunt kan dienen voor de verzameling van gegevens uit het studie-informatiesysteem (of studenteninformatiesysteem, SIS) van de lerarenopleidingen.

\section{Aanpak volgens Nationaal Cohortonderzoek Onderwijs (NCO)}

De lerarendatabase kan worden opgezet vanuit het Nationaal Cohortonderzoek Onderwijs (NCO, zie https://nationaalcohortonderzoek.nl/), dat op initiatief van het NRO tot stand is gekomen. Dit geldt in het bijzonder voor de aanpak ten aanzien van de gegevensverwerking en privacy. Daarom is gekozen voor de volgende aanpak:

- Ten eerste dienen hogescholen, NRO en CBS een regeling verwerkingsverantwoordelijken overeen te komen ten behoeve van de lerarendatabase. Daarin dient de grondslag voor verwerking van studentgegevens te worden opgenomen.

- De grondslag voor verwerking van studentgegevens door hogescholen voor de lerarendatabase is gelegen in Artikel 1.18 WHW: Het instellingsbestuur van een instelling voor hoger onderwijs draagt er zorg voor dat, zoveel mogelijk in samenwerking met andere instellingen, wordt voorzien in een regelmatige beoordeling, mede door onafhankelijke deskundigen, van de kwaliteit van de werkzaamheden van de instelling. De beoordeling geschiedt mede aan de hand van het oordeel van studenten over de kwaliteit van het onderwijs van de instelling. Het deel van de beoordeling dat is uitgevoerd door onafhankelijke deskundigen wordt door het instellingsbestuur openbaar gemaakt. Bij de beoordeling worden de uitkomsten van eerdere beoordelingen betrokken.

- Verdere verwerking van deze persoonsgegevens door onderzoekers is mogelijk conform de uitzonderingsbepaling voor wetenschappelijk onderzoek waarmee wordt voldaan aan het vereiste van doelbinding (art. 5 lid 1 sub b jo. art. 89 lid 1 AVG). Daarbij wordt voldaan aan de eis dat de verdere verwerking van persoonsgegevens verenigbaar moet zijn met de doeleinden waarvoor de gegevens aanvankelijk zijn verzameld (art. 6 lid 4 AVG). 
- Het CBS werkt op basis van de CBS-wet en dit biedt de grondslag voor verwerking van deze persoonsgegevens.

- Dit betekent dat voor verwerking van studentgegevens voor wetenschappelijk onderzoek via de lerarendatabase bij het CBS geen toestemming hoeft te worden gevraagd aan studenten.

- Daarbij gaan we ervan uit dat de database geen bijzondere persoonsgegevens bevat. Gegevensverzameling over ras of etnische afkomst (inclusief huidskleur, nationale afkomst), politieke opvattingen, religieuze of levensbeschouwelijke overtuigingen, of het lidmaatschap van een vakbond, genetische gegevens, biometrische gegevens met het oog op de unieke identificatie van een persoon (zoals herkenbare personen op foto's en in films), of gegevens over gezondheid (fysiek of mentaal, ruime interpretatie, betreft verleden, heden en toekomst), of gegevens met betrekking tot iemands seksueel gedrag of seksuele gerichtheid is verboden (artikel 9 lid 1 AVG, art. 4 lid 13, 14 AVG, overweging 51 AVG).

- De lerarendatabase bevat studentgegevens van hogescholen. Dit betekent ten aanzien van de AVG dat ouders geen rol spelen. Studenten dienen direct geïnformeerd te worden over de verwerking van hun persoonsgegevens. Belangrijk is de informatieverplichting: Studenten moeten door het bestuur van de hogeschool worden geïnformeerd (via folders, website of schoolblad) dat hun gegevens uit het SIS (studie- of studenteninformatiesysteem) van de lerarenopleidingen kunnen worden geüpload en gekoppeld aan andere gegevens. Studenten kunnen bezwaar maken tegen verwerking van hun persoonsgegevens voor de lerarendatabase, waarvoor een apart bezwaarbestand bij de hogescholen en softwareleveranciers dient te worden aangemaakt (op dezelfde wijze als bij de levering van gegevens uit LVS aan CBS). Gegevens over deze studenten worden niet geleverd aan het CBS. Het NCO zal hiervoor een standaardtekst aanleveren aan de hogescholen om te gebruiken.

- Ook gegevens van oud-studenten kunnen door hogescholen geüpload worden naar het CBS, zonder toestemming van deze studenten. Deze oud-studenten dienen hierover te worden geïnformeerd via de correspondentie met alumni en daarbij de gelegenheid te krijgen bezwaar te maken.

- Doordat er een beperkt aantal hogescholenis kan er gemakkelijk direct met de hogescholen worden gesproken over de grondslag voor verwerking van persoonsgegevens en de te volgen procedures. We denken daarbij eerst aan alle hogescholen die een PABO hebben, in het bijzonder de hogescholen die verenigd zijn bij Radiant Lerarenopleidingen. In tweede instantie denken we aan alle hogescholen die een PABO hebben en aangesloten zijn bij de LOBO, dus ook de brede hogescholen. In derde instantie denken we aan de overige lerarenopleidingen van de hogescholen die een PABO hebben en die al mee willen doen voor de PABO.

- Na toestemming van een voldoende aantal hogescholen (bijvoorbeeld minimaal vijf, zie verder hieronder bij de voorwaarden van het CBS over het breed maatschappelijk belang dat moet worden gediend) kan met deze scholen het samenstellen en uploaden van databestanden voor datatransmissie naar het CBS worden opgestart. Dat wil zeggen dat we willen beginnen met een beperkt aantal variabelen uit de 
administratieve systemen waarvan kan worden verwacht dat ze redelijk goed vergelijkbaar zijn tussen de verschillende hogescholen.

- Er zijn enkele softwareleveranciers voor het hoger onderwijs. Zij kunnen vanuit hun servers direct aan het CBS de benodigde gegevens leveren volgens de daarvoor geldende uploadprocedure van het CBS. Hogescholen en softwareleveranciers kunnen afspraken hierover toevoegen aan bestaande verwerkersovereenkomsten of aanvullende overeenkomsten afsluiten. Belangrijke softwarepakketten zijn Trajectplanner, Osiris, Progress, SaNS en Alluris. Sommige van deze pakketten worden echter uitgefaseerd; Osiris lijkt als belangrijkste aanbieder voor Radiant over te blijven.

- $\quad \mathrm{NRO}$ (NCO) en CBS dragen er zorg voor dat de data in de lerarendatabase bij het CBS worden gekoppeld, volgens de richtlijnen van het CBS, met andere register-en enquêtebestanden die bij het CBS beschikbaar zijn, en leiden tot instellingsrapportages die zo spoedig mogelijk vanuit het CBS worden geleverd aan de instellingen. Verder kunnen onderzoekers onder de algemeen geldende voorwaarden van het CBS de data uit de lerarendatabase gebruiken voor verder onderzoek. Het NRO zal dit voor zover mogelijk stimuleren.

\section{Voorwaarden CBS}

In aanvulling op het bovenstaande heeft het CBS meerdere voorwaarden om akkoord te kunnen gaan met het uploaden van gegevens over studenten van de lerarenopleidingen.

- Het doel van het project mag niet alleen zijn om de bedrijfsvoering van een enkele hogeschool te verbeteren. Het moet gaan om het dienen van een breed algemeen maatschappelijk belang, in dit geval de optimalisatie van de curricula van alle lerarenopleidingen in Nederland, ook al zal er niet onmiddellijk een volledige deelname zijn van al deze lerarenopleidingen. Het voorgestelde project is een pilotproject met de Radiant Lerarenopleidingen (bijvoorbeeld minimaal vijf lerarenopleidingen), waarbij er interesse is vanuit de andere lerarenopleidingen om (eventueel later) aan te sluiten. Daarnaast is ook het dienen van de wetenschap een gerechtvaardigd belang.

- Aanlevering van de gegevens vanuit de softwareleverancier gaat volgens de standaard aanleveringsprocedure van het CBS. Zie daarvoor https://www.cbs.nl/microdata en https://www.cbs.nl/nl-nl/onzediensten/maatwerk-en-microdata/microdatazelf-onderzoek-doen/importvan-eigen-bestanden.

- De kosten van uploaden zijn 210 euro per bestand. Aangeraden wordt om zoveel mogelijk bestanden samen te voegen vóór de aanlevering naar CBS, dit bespaart tijd en geld.

- De kosten voor de versleuteling bedragen eveneens 210 euro bij aanlevering van BSN of onderwijsnummer. Bij aanlevering van geboortedatum, geslacht, adres bedragen de kosten 650 euro per bestand omdat de versleuteling dan complexer is. Dit laatste valt niet aan te bevelen omdat het onderwijsnummer op zich voldoende informatie 
biedt. Op basis daarvan kan binnen het CBS gekoppeld worden en komen de achtergrondgegevens naar boven.

- Uitgangspunt is, volgens de richtlijnen van het CBS, dat gegevens die geëxporteerd of gepubliceerd worden op basis van de bestanden die bij het CBS worden gebruikt, nooit herleidbaar mogen zijn tot individuele personen of instellingen (tenzij er een gegronde reden is om aan te nemen dat bij de betrokken instelling geen bedenkingen bestaan tegen de openbaarmaking, zie art. 37 lid 3 CBS-wet). Het CBS sluit hiertoe al standaard aparte overeenkomsten af met de gebruikers van de gegevens. Voor de instellingsrapportages die op basis van de lerarendatabase tot stand komen en vanuit CBS/NRO worden geleverd aan hogescholen wordt er gewerkt op basis van de vooraf gemaakte regeling voor gezamenlijke verwerkingsverantwoordelijken. Daarnaast kunnen er onderzoekers werken met de data in de lerarendatabase bij het CBS. Wanneer onderzoekers op basis hiervan willen rapporteren op instellingsniveau zullen CBS/NRO verifiëren bij CvB's van de hogescholen of er een gegronde reden is om aan te nemen dat bij de betrokken instelling geen bedenkingen bestaan tegen openbaarmaking van dergelijke gegevens. We kunnen ervan uitgaan dat het CBS de levering van instellingsrapportages formeel doet, maar dat een onderzoeker (hetzij via NCO of onder verantwoordelijkheid van NCO) het rapport maakt.

\section{Plan van aanpak voor gegevensaanlevering aan CBS in zes fases}

We gaan ervan uit dat er een beperkt aantal partijen is dat in het plan van aanpak een rol speelt: het NRO (NCO) dat verantwoordelijk is voor de coördinatie en uitvoering van het project; het bestuur van de hogeschool (College van Bestuur, CvB) en de informatiespecialisten die door het CVB gemandateerd zijn om handelingen te verrichten in het administratiesysteem van de hogeschool (vergelijkbaar met handelingen voor DUO); de softwareleverancier die in opdracht van de hogeschool handelt en de levering van gegevens direct aan het CBS verzorgt; het CBS dat zorgt voor de koppeling van gegevens, ondersteuning van alle partijen en dat de gegevens op een juiste wijze naar buiten kunnen gaan via de instellingsrapportage en voor verder gebruik voor wetenschappelijk onderzoek. De softwareleverancier moet een gegevensaanlevertool programmeren die voldoet aan de voorwaarden van het CBS (zie hierboven) en ook de studenten registreert die niet willen dat hun gegevens worden doorgeleverd aan het CBS. Hieronder is het plan van aanpak opgedeeld in zes fases vanaf de start van de deelname van een hogeschool aan de lerarendatabase.

Fase 1: Aanmelding en voorbereiding (maand o-4)

- Het CvB geeft schriftelijk aan het NRO (NCO) door welke lerarenopleidingen onder dit bestuur mee willen doen met het onderzoek voor het samenstellen van een lerarendatabase, inclusief het uitbrengen van instellingsrapportages. gegevens gebruikt kunnen worden voor wetenschappelijk onderzoek op basis van de overeenkomst tussen hogescholen, CBS en NRO. 
- Het CvB geeft het NRO (NCO) een lijst met crohonummers van de lerarenopleidingen die mee willen doen.

- Het NRO (NCO), CBS en deelnemende hogescholen sluiten een gezamenlijke regeling verwerkingsverantwoordelijken (overeenkomst) af ten behoeve van de lerarendatabase.

- Daarbij stellen de bovengenoemde partijen vast welke gegevens er voor de datatransmissie nodig zijn in het kader van het onderzoek, hetgeen wordt vastgelegd in een codeboek, evenals de noodzakelijke identificatiegegevens en de informatie over de lerarenopleiding.

- Het NRO (NCO) voorziet het CvB van het benodigde voorlichtingsmateriaal voor studenten.

- Het CvB licht studenten tijdig, goed en schriftelijk voor over het besluit deel te nemen aan het onderzoek, en wijst ze op de mogelijkheid bezwaar te maken tegen het delen van gegevens.

- De hogeschool en de softwareleverancier vullen de bestaande verwerkersovereenkomst aan of sluiten een aanvullende overeenkomst af ten behoeve van de datalevering aan het CBS. Het initiatief hiertoe ligt bij de hogeschool.

Fase 2: Implementatie van de gegevensaanlevertool in het administratiesysteem van de hogeschool van de deelnemende lerarenopleidingen (maand 3-8)

- Het NRO (NCO) verzoekt de softwareleverancier om het CvB van de deelnemende hogescholen te voorzien van de aanlevertool voor de betreffende lerarenopleidingen.

- De softwareleverancier implementeert de gegevensaanlevertool door een update in het administratiesysteem bij deze lerarenopleidingen.

- Het NRO (NCO) communiceert met het CvB in algemene zin over de technische veranderingen in het administratiesysteem (aansluitend aan de update). Hiervoor ontvangt het NRO (NCO) van de softwareleverancier een handleiding of brief die meegestuurd wordt.

- Daarbij wordt expliciet toegelicht dat alleen gegevens van lerarenopleidingen waarop de overeenkomst betrekking heeft worden geleverd aan het CBS.

Fase 3: Bezwaarperiode: studenten kunnen bezwaar maken tegen aanlevering van hun gegevens, en CvB's administreren de bezwaren (maand 9-12)

- Studenten die niet willen dat hun gegevens met het CBS en het NRO (NCO) gedeeld worden, maken hiertegen schriftelijk bezwaar. Daarvoor hebben ze vier maanden de tijd.

- Het CvB ontvangt een schrijven met het verzoek van studenten om hun gegevens niet op te nemen in de lerarendatabase.

- Het CvB registreert dat studenten bezwaar maken. Ook meegenomen worden de bezwaren van studenten die in voorgaande jaren bezwaar tegen levering hebben gemaakt, voor zover deze al niet bij het CBS zijn registreert. 
- Het CvB geeft na afloop van de bezwaarperiode opdracht aan de eigen informatiespecialisten om de handelingen te verrichten die voorkomen dat gegevens van de studenten die bezwaar hebben gemaakt worden doorgeleverd aan CBS.

Fase 4: Voorbereiden levering: Informatiespecialisten van de hogescholen verrichten de noodzakelijke handelingen om de dataleveringen voor te bereiden (maand 9-12)

- Informatiespecialisten van de hogeschool gemandateerd door het CvB loggen op de gebruikelijke wijze in het administratiesysteem in en vinken alle namen uit van studenten die recent of in het verleden bezwaar hebben gemaakt tegen de levering van gegevens aan CBS.

- De informatiespecialist kan een afschrift afdrukken met daarop de studenten die niet mee mogen in de export.

- Het CvB controleert dat gegevens van de studenten die bezwaar hebben gemaakt niet gedeeld worden met het CBS.

- De informatiespecialist moet bevestigen dat deze klaar is met het aangeven van de bezwaarstudenten en dat het afschrift door het CvB is gecontroleerd. Dat kan door in een daartoe bestem de box een bevestigend vinkje te plaatsen (verplicht).

- Er wordt een log aangemaakt waarin wordt opgenomen wie bevestigd heeft.

Fase 5: Softwareleveranciers leveren de gegevens uit het SIS aan het CBS (maand 13-14)

- Het NRO (NCO) communiceert met het CvB dat de voorgenomen datatransmissie aanstaande is, en geeft daarvoor de exacte peildatum.

- Het CvB van een hogeschool laat schriftelijk aan het NRO (NCO) weten dat de studenten goed zijn voorgelicht, dat de bezwaarprocedure verlopen is, dat de bezwaren zijn verwerkt, en dat de verwerking is gecontroleerd. Men geeft ook het aantal ingekomen bezwaarschriften op.

- Het NRO (NCO) communiceert met de softwareleverancier de periode tijdens welke de voorgenomen transmissie van data van studenten (op peildatum) zal plaatsvinden.

- Het NRO (NCO) vraagt het CBS het project en bijbehorend projectnummer aan te maken en communiceert dit nummer, alsmede richtlijnen voor uploadprocedure, met de softwareleverancier van elk hogeschool.

- Op de overeengekomen datum/tijd maakt de softwareleverancier de gegevens en identificatiegegevens uit de eigen gegevensbank klaar voor levering aan het CBS, en levert deze volgens de leveringsprocedures van het CBS aan het CBS. Daarbij wordt het format zoals aangegeven in het codeboek in acht genomen.

- Softwareleverancier verzendt de gegevens volgens de daarvoor vigerende CBS-richtlijnen aan het CBS.

- Het CBS plaatst na ontvangst de versleutelde gegevens op een beveiligde server, ontsleutelt en pseudonimiseert de gegevens volgens de aldaar gebruikelijke procedure, en stelt de gepseudonimiseerde gegevens ter beschikking aan het NRO (NCO) via de gebruikelijke procedure (Remote Access). 
Fase 6: Nazorg en support

- Hogescholen en lerarenopleidingen die technische vragen hebben over het softwarepakket kunnen volgens de daartoe gebruikelijke kanalen terecht bij de softwareleverancier.

- Hogescholen en lerarenopleidingen die specifieke aan het onderzoek gerelateerde vragen hebben, kunnen daartoe terecht bij het NRO (NCO).

- De instellingsrapportages kunnen via softwarepakketten met scholen worden gedeeld, hetzij in rapportvorm, dan wel in de vorm van door het NRO (NCO) of de softwareleveranciers te ontwikkelen informatieproducten.

- Daarnaast kunnen onderzoekers de gegevens uit de lerarendatabase bij het CBS gebruiken voor verder onderzoek onder de hierboven beschreven condities. 



\section{SLOT}

De lerarendatabase die we in deze pilotstudie voorstaan bevat gegevens van studenten en curricula van de lerarenopleidingen gecombineerd met extern beschikbare gegevensbestanden. Daarbij gaat het er om de intrede en kenmerken van studenten, hun voortgang in de studie en de mobiliteit en het succes van (beginnende) leraren op de arbeidsmarkt over opleidingen heen vergelijkbaar te maken. Dit kan nieuwe inzichten geven in de effecten van het ene ten opzichte van het andere curriculum op de onderwijs- en arbeidsloopbaan van leraren. Ook kunnen patronen in de curricula en de kenmerken van studenten en afgestudeerden van lerarenopleidingen aan het licht komen die nu onopgemerkt blijven.

Gegevens over de lerarenopleidingen en hoe de aankomende leraren deze hebben doorlopen zijn bovendien een ontbrekende schakel ('black box') in de veelheid van data die al beschikbaar zijn over de studenten vóórdat ze beginnen aan de lerarenopleiding en nádat ze de lerarenopleiding hebben afgerond. De informatie over de voortgang en studieprestaties tijdens de lerarenopleidingen lijkt het belangrijkste ontbrekende onderdeel in de schoolloopbaan van afgestudeerde leraren, dat wellicht ook voorspellende waarde heeft voor de verdere beroepsloopbaan binnen of buiten het onderwijs. De diverse mogelijkheden voor koppeling van variabelen over lerarenkenmerken en hun school- en beroepsloopbaan voor, tijdens en na de lerarenopleiding zijn uitgebreid toegelicht in het derde hoofdstuk van dit rapport.

De lerarenopleidingen krijgen door het samenstellen van de lerarendatabase de gelegenheid tot benchmarking van hun opleidingen in de vorm van instellingsrapportages. Door nadere duiding, interpretatie en aanvullend onderzoek door de lerarenopleidingen zelf kunnen de lerarendatabase en de benchmarking bijdragen aan de optimalisatie van de curricula. Om het gebruik van de inzichten te stimuleren zou het leren van elkaar en niet het geven van kwaliteitsoordelen centraal moeten staan.

Bij aanvang van deze pilotstudie was voorzien dat de hogescholen zelf de aanlevering van gegevens uit het studie- of studenteninformatiesysteem (SIS) aan het CBS voor hun rekening zouden nemen. Gaandeweg het onderzoek bleek echter dat dit geen haalbare kaart was en dat de softwareleveranciers van de hogescholen de aangewezen partner zijn voor de datatransmissie naar het CBS. Hoewel wij contact hebben gehad met enkele softwareleveranciers, vraagt de afstemming met deze partijen wel nog enige aandacht. 
Niet alleen is de markt van deze leveranciers in beweging, waardoor oude aanbieders afvallen en nieuwe pakketten opkomen, ook moeten er contracten tussen hogescholen en softwareleveranciers worden aangepast. Op basis van de bevindingen in dit rapport en afgaande op de ervaringen bij het Nationaal Cohortonderzoek Onderwijs (NCO) denken we dat dit mogelijk moet zijn.

Het is daarbij om te beginnen van groot belang dat het NRO (NCO), CBS en de hogescholen van Radiant Lerarenopleidingen een gezamenlijke regeling verwerkingsverantwoordelijken (overeenkomst) afsluiten ten behoeve van de lerarendatabase. Hiervoor is in dit rapport een stappenplan met zes fases geschetst. Wat betreft de deelname van hogescholen betreft het hier met name de (vijf) Radiant Lerarenopleidingen die gezamenlijk optrekken in de aanbesteding van de diensten van een softwareleverancier. Onmiddellijk daarop volgend kan ook gepoogd worden om de vier andere hogescholen van Radiant Lerarenopleidingen erbij te betrekken. Deze hogescholen hebben echter andere softwareleverancies met andere voorwaarden en procedures. De hogescholen en de softwareleverancier(s) dienen hun bestaande verwerkersovereenkomst aan te passen of sluiten een aanvullende overeenkomst af ten behoeve van de datalevering aan het CBS. Voor de aanlevering van gegevens voor de lerarendatabase aan het CBS is een vereiste dat hogescholen toestemming geven en dat zij eerst hun studenten de gelegenheid geven bezwaar te maken tegen de aanlevering. Vervolgens kunnen de gegevens over de studievoortgang van studenten direct worden gebruikt voor de lerarendatabase en de instellingsrapportages. We stellen voor meteen instellingsrapportages te maken die gegevens over de voortgang van de studenten van de lerarenopleidingen bevatten.

Uit het onderzoek is verder gebleken dat de interesse bij de PABO's in het algemeen, en niet alleen bij de Radiant Lerarenopleidingen, groter is dan we eerder dachten. Hoewel met de nodige reserves, ziet men wel de potentiële waarde van instellingsrapportages voor de optimalisatie van curricula. De reserves betreffen voorzichtigheid ten aanzien van de privacy van studenten, de interpretatie en duiding van kwantitatieve gegevens, en zorgen over het onjuiste gebruik van deze gegevens bij kwaliteitsoordelen (bij bijvoorbeeld door het ministerie van OCW of de Inspectie van het Onderwijs). Het is dan ook van het grootste belang om hier voldoende waarborgen voor de lerarenopleidingen voor in te bouwen.

Verder is gebleken dat het verzamelen van gegevens zich niet hoeft te beperken tot het Studie- of Studenteninformatiesysteem (SIS) van de Radiant Lerarenopleidingen, maar eenvoudig kan worden uitgebreid tot de lerarenopleidingen van andere hogescholen en universiteiten. Wel vereist het per combinatie van onderwijsinstelling en softwareleverancier een aparte 'aanvliegroute' om de deelname aan de lerarendatabase te stimuleren, wat de nodige tijdsinvestering met zich mee kan brengen. Het verdient dan ook de aanbeveling om de deelname zoveel als mogelijk via de koepelorganisaties (zoals de LOBO) te laten verlopen, en volgens gestandaardiseerde procedures. 


\section{BIJLAGE A}

Voor de totstandkoming van dit rapport zijn er diverse bijeenkomsten gehouden en is er gesproken met medewerkers van de studentenadministratie van hogescholen (van Radiant) die uitsluitend lerarenopleidingen (incl. PABO) aanbieden of een brede hogeschool zijn. Daarnaast zijn er ook medewerkers van andere organisaties geïnterviewd, zoals het CBS, de LOBO en de Inspectie van het Onderwijs.

\begin{tabular}{|c|c|c|c|}
\hline Organisatie & Contactpersoon & Datum & Functie \\
\hline Iselinge & $\begin{array}{l}\text { Gerald Aalders } \\
\text { Gerdo Velthorst }\end{array}$ & 23-01-'19 & $\begin{array}{l}\text { Medewerkers studentzaken } \\
\text { Onderwijsbureau } \\
\text { STIP (Studentinformatiepunt) }\end{array}$ \\
\hline CHE & $\begin{array}{l}\text { Sophia Boom } \\
\text { Harm van den Berg }\end{array}$ & 08-03-'19 & $\begin{array}{l}\text { Hoofd Studentzaken } \\
\text { Dienst Service en Expertise } \\
\text { Coördinator bovenbouw }\end{array}$ \\
\hline Driestar & Kees Codée & 24-01-'19 & Manager support \\
\hline De Kempel & Ellen Hart & 22-01-'19 & Medewerker studentenadministratie \\
\hline Thomas Moore & Odette Baars & 31-01-'19 & Manager bedrijfsvoering en kwaliteit \\
\hline $\begin{array}{l}\text { Zuyd/ De Nieuwste Pabo } \\
\text { Fontys/ De Nieuwste Pabo }\end{array}$ & $\begin{array}{l}\text { Paul Reijns } \\
\text { Marcel Starmans } \\
\text { Paul Hennissen }\end{array}$ & $\begin{array}{l}30-01-' 19 \\
20-09-' 18\end{array}$ & $\begin{array}{l}\text { Beleidsadviseur } \\
\text { Informatiespecialist } \\
\text { Lector Opleiden in de School }\end{array}$ \\
\hline Iddink Group (Alluris) & Albert Bouwman & $15-02-{ }^{\prime} 19$ & Product owner / manager \\
\hline Fringe (Trajectplanner) & Jeroen Platvoet & $12-02-' 19$ & Operationeel directeur \\
\hline Caci (0siris) & Susanne Zuurendonk & 04-06-'19 & Manager Professional Services \\
\hline $\begin{array}{l}\text { Centraal Bureau voor de Statistiek } \\
\text { (CBS) }\end{array}$ & Ivo Gorissen & $15-03-' 19$ & Account manager \\
\hline $\begin{array}{l}\text { Landelijk Overleg Lerarenopleiding } \\
\text { Basisonderwijs (LOBO) }\end{array}$ & $\begin{array}{l}\text { Barbara de Kort } \\
\text { Afgevaardigden hogescholen }\end{array}$ & $\begin{array}{l}30-08-' 18 \\
17-01-' 19\end{array}$ & $\begin{array}{l}\text { Voorzitter LOBO } \\
\text { Directeuren }\end{array}$ \\
\hline $\begin{array}{l}\text { Nationaal Cohortonderzoek } \\
\text { Onderwijs (NCO) }\end{array}$ & Mark Levels & 05-02-'19 & Projectcoördinator NCO \\
\hline Inspectie van het Onderwijs & Tijana Breuer & 28-03-'19 & Senior onderzoeker \\
\hline
\end{tabular}





\section{BIJLAGE B}

Hier volgt een overzicht van alle relevante databestanden die al in een CBS-omgeving beschikbaar gemaakt kunnen worden voor het onderzoek naar leraren. Dit geeft een beeld van wat op dit moment mogelijk is en ook al door diverse onderzoeksgroepen in Nederland (CPB, UvA, Academische Werkplaats Onderwijs UM) wordt gedaan. Eerst komen de bestanden met leraarkenmerken aan de orde, vervolgens de arbeidsmarktbestanden. Ten slotte de bestanden met informatie over de scholen waar de leraren werkzaam zijn.

\section{Bestanden met kenmerken van leraren}

\section{a. DUO}

1cijferHO in-en uitstroombestand 2001-heden:

Alle inschrijvingen in het (bekostigd) hoger onderwijs zijn hierin geregistreerd. Het bestand beslaat de cohorten die vanaf 2001 zijn ingestroomd. Voor de lerarenanalyses kan hiermee geïdentificeerd worden wie er de lerarenopleiding heeft gevolgd.

Leerlingen PO bestanden 2008-heden:

Dit bestand bevat inschrijvingsinformatie per basisschoolleerling, achtergrondkenmerken, eventuele cito-scores etc. voor de jaren vanaf 2008 tot heden. Voor de meest recent instromende cohorten in de lerarenopleiding is er op basis van dit bestand informatie over hun cito-scores en schooladvies.

\section{b. CBS}

Examenuitslagen per vak van leerlingen in het voortgezet onderwijs (EXAMVOVAKTAB) 2006- heden:

Voor alle scholieren die hun VO eindexamen gedaan hebben in deze periode staan in deze bestanden hun CE en Schoolexamencijfers. Deze bestanden kunnen gekoppeld worden aan het 1cijferHO bestand om voor de instromers vanaf 2006 hun eindexamencijfers mee te nemen in de analyses. 
In de Gemeentelijke Basisadministratie Persoonsgegevens (GBA) ingeschreven personen en hun juridische ouders (Kindoudertab) 1995- heden:

Met dit hulpbestand kunnen studenten aan hun ouders gekoppeld worden. Dit is relevant voor analyses met betrekking tot de sociaaleconomische status van studenten.

\section{Hoogst behaalde en hoogst gevolgde opleidingsniveau en opleidingsrichting van de} bevolking in Nederland (Hoogsteopltab) 1999- heden:

Dit bestand kan worden gebruikt om het opleidingsniveau van de ouders van de studenten in het HO-bestand te bepalen. Voor de leraren die te oud zijn om in het HO-bestand voor te komen (diploma behaald voor 2001) kan hiermee ook de hoogst gevolgde opleiding bepaald worden (bijvoorbeeld of een bepaalde leraar een masterdiploma heeft). Dit bestand is opgebouwd op basis van alle personen die ooit aan de Enquête Beroepsbevolking (EBB) mee hebben gedaan. Het is dus niet $100 \%$ dekkend, maar bevat voor 11 miljoen mensen hun hoogst behaalde opleiding.

Integraal huishoudensinkomen (IHI) 2003- heden:

Dit bestand bevat per jaar per huishouden het bruto-inkomen, en het inkomenspercentiel waarin het huishouden in dat jaar viel. Dit bestand kan gebruikt worden om de inkomenssituatie van de gezinnen van de studenten te bekijken in de jaren voordat zij zich voor de lerarenopleiding hebben ingeschreven.

\section{Arbeidsmarktbestanden}

\section{a. CBS}

Banen en lonen van werknemers in Nederland (SPOLISBUS) 2007-heden:

Deze jaarbestanden bevatten maandelijkse loonadministratie van alle banen van werknemers bij Nederlandse bedrijven. Hier kan uit geput worden voor o.a. uurloon, gewerkte uren, type contract (vast/tijdelijk bepaald/onbepaalde tijd), en werkgeversinformatie van afgestudeerden van de lerarenopleidingen.

\section{Bedrijven uit de Polisadministratie met hun economische activiteit en grootteklasse (BETAB):}

Polis heeft beperkte informatie over de sector waarin bedrijven werkzaam zijn. Dit maakt het lastig om te zien wie er in het onderwijs werkt. Met het BETAB bestand kan er voor alle bedrijven de economische sector (SBl2008) achterhaald worden. Hiermee zien we dus wie er in het onderwijs werkt, en in welke sector van de economie leraren die uitvallen terecht komen.

\section{b. DUO}

\section{Functiemixbestand 2006-heden:}

Met BETAB is het mogelijk leraren op bestuursniveau te identificeren, maar niet om ze te koppelen aan een bepaalde school. Met het Functiemixbestand kunnen leraren op 
BRIN-niveau gekoppeld worden. Het functiemixbestand is in principe op persoonsniveau beschikbaar (dus niet de openbare versie met gemiddelden per BRIN of bestuur).

\section{IPTO 2013-heden:}

De IPTO bestanden bevatten informatie over leraren werkzaam in het voortgezet onderwijs. De toegevoegde waarde van deze bestanden is dat het mogelijk is leraren op BRINvest niveau te identificeren, wat met alleen de Functiemixbestanden niet kan. De bestanden kunnen door DUO worden aangeleverd met een beperkt aantal variabelen.

\section{Informatie over de scholen waaraan afgestudeerde leraren werkzaam zijn (DUO)}

Zeer interessant is dat leraren gekoppeld kunnen worden aan de precieze BRIN waarop ze werkzaam zijn voor de jaren vanaf 2006 dankzij de combinatie van de 1cijferHO, SPOLISBUS, en Functiemixbestanden. Voor deze scholen kunnen er dan weer schoolkenmerken toegevoegd worden uit de bestanden op leerlingniveau door ze op BRINniveau te aggregeren. Hieronder staan de bestanden die hiervoor geschikt zijn.

Leerlingen PO en SBO 2008-heden:

Dit bestand bevat inschrijvingsinformatie per basisschoolleerling, achtergrondkenmerken, eventuele cito-scores etc. voor de jaren vanaf 2008. Door deze data op BRINniveau te aggregeren kan per school het aantal leerlingen, aandeel meisjes, percentage allochtonen, gemiddeld cito-niveau etc. achterhaald worden, en gekoppeld worden aan de leraren die op deze BRIN werkzaam zijn.

Leerlingen VO 2003-heden:

Dit bestand bevat inschrijvingsinformatie per leerling van een middelbare school voor de jaren vanaf 2003. Met het eerdergenoemde examenvakkenanalysebestand kunnen voor deze scholen ook de gemiddelde eindexamenprestaties gekoppeld. Net als de PO-leerlingendata kunnen deze data op BRIN en vanaf 2013 zelfs BRINvest geaggregeerd worden om te koppelen aan de leraren die er werkzaam zijn. 



\section{BIJLAGE C}

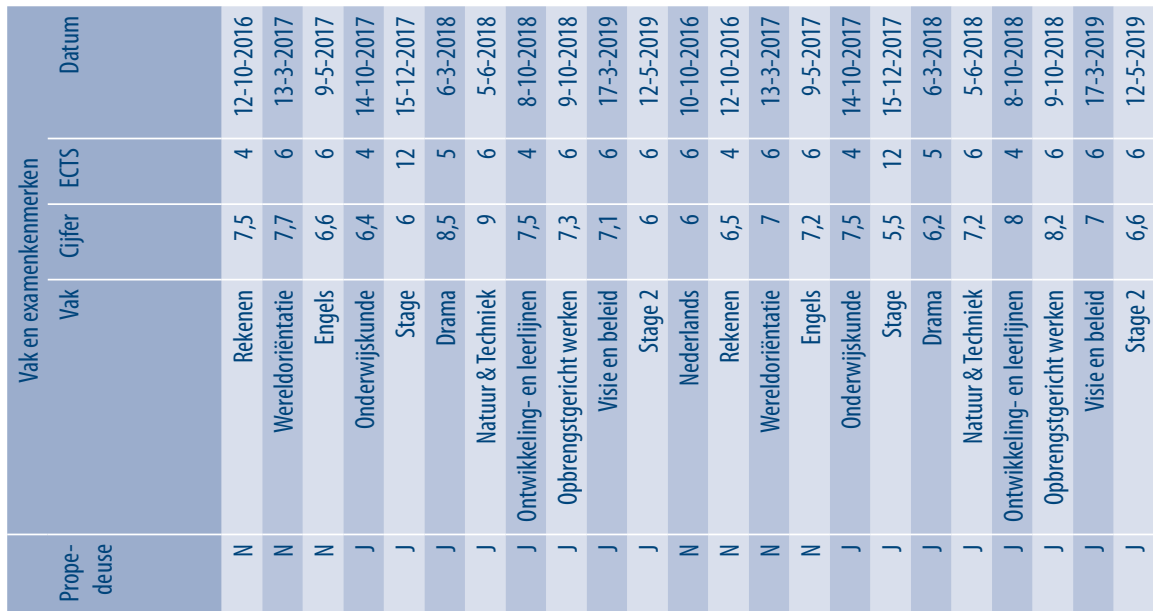

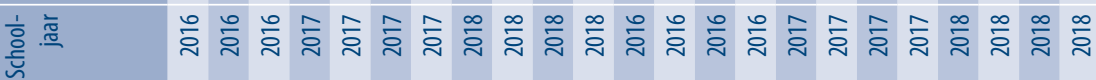

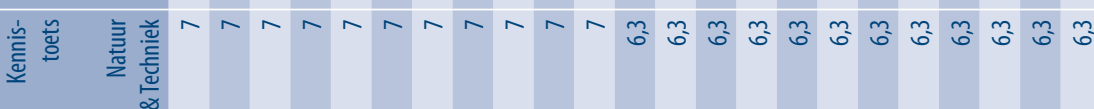

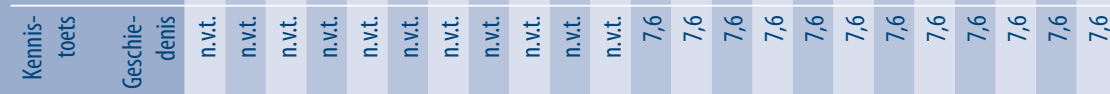

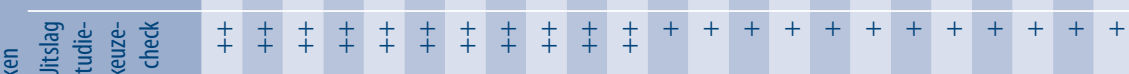
离

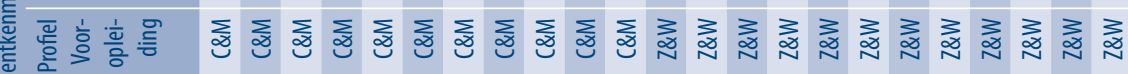

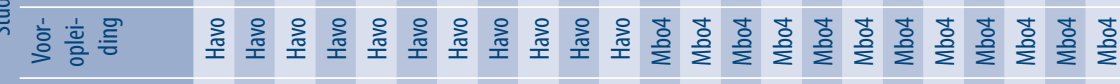

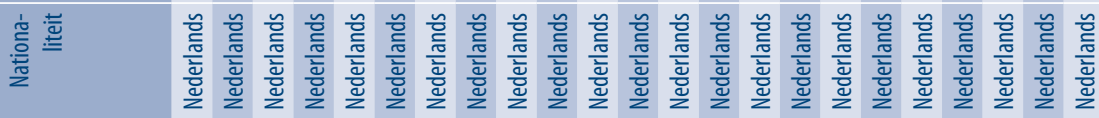

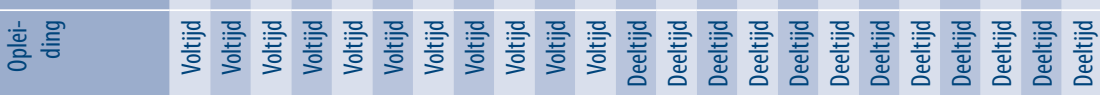

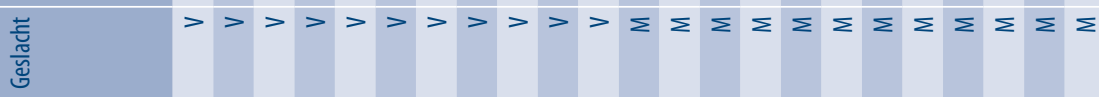

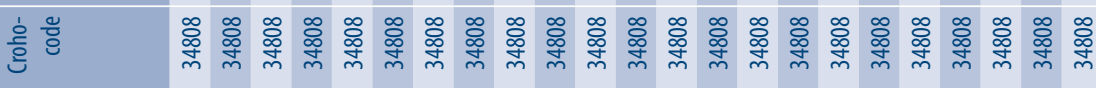

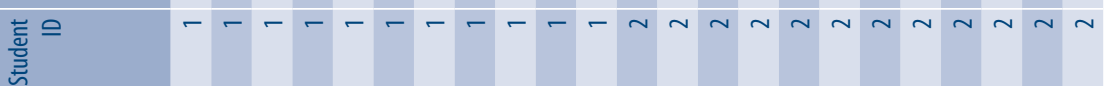


